\title{
KONDISI INTRUSI AIR LAUT TERHADAP KONDISI KUALITAS AIR TANAH DI KOTA SURABAYA
}

\author{
Galdi Ariyanto ${ }^{1)}$, Mas Agus Mardyanto ${ }^{2)}$ \\ 1) Mahasiswa Program Studi Pascasarjana Teknik Lingkungan, ITS-Surabaya \\ 2) Staff Pengajar Program Studi Pascasarjana Teknik Lingkungan, ITS-Surabaya \\ Kampus ITS Sukolilo Surabaya 60111 \\ Email : galdi14@mhs.enviro.its.ac.id; mardyanto@enviro.its.ac.id
}

\begin{abstract}
Abstrak
Surabaya adalah salah satu kota pesisir yang ada di Indonesia. Salah satu permasalahan wilayah kota pesisir adalah adanya instrusi air laut. Intrusi air laut adalah menyusupnya air laut ke zona air tawar sehingga air tawar berasa asin. Permasalahan pokok sumberdaya air yang terjadi di beberapa kota besar di Indonesia antara lain keragaman sistem akuifer, posisi dan penyebaran penyusupan/intrusi air laut baik secara alami maupun secara buatan yang diakibatkan adanya pengambilan air tanah berlebihan (mining yield) untuk kebutuhan domestik, maupun industri. Tujuan dari penelitian ini adalah untuk mengetahui sebaran kawasan terintrusi air laut di Kota Surabaya berdasarkan kandungan klorida $(\mathrm{Cl})$ dalam air. Pengambilan sampel air dilakukan di 28 titik untuk selanjutnya dilakukan analisi laboratorium. Berdasarkan hasil analisis data, diketahui bahwa $23 \%$ wilayah di Kota Surabaya kondisi kualitas air tanahnya asin, $26 \%$ payau dan sisanya pada kondisi tawar. Dibandingkan dengan tahun 2013, wilayah yang terintrusi air laut di Kota Surabaya mengalami penurunan, sehingga menunjukkan bahwa telah terjadi peningkatan kondisi kualitas air tanah di Kota Surabaya.
\end{abstract}

Kata kunci: Intrusi Air Laut, Air Tanah, Kota Surabaya

\begin{abstract}
Surabaya is one of the coastal cities in Indonesia. One of the problems of coastal areas of the city is the presence of sea water intrusion. Intrusion of sea water is infiltration of seawater into freshwater zones. The main problem water resource in several major cities in Indonesia is the diversity of the aquifer system, positioning and deployment of intrusion/intrusion of sea water either naturally or artificially caused the excessive ground water extraction (mining yield) for domestic, as well as industry. The aim of this study was to determine the distribution of sea water intruded area in Surabaya based on the content of chloride $(\mathrm{Cl})$ in ground water. Water sampling conducted in 28 point for further laboratory analysis. The results shows that the research area has a salty water area of 7.485 ha (23\%), of brackish water area of 8.492 ha (26\%) and fresh water area of $16.870 \mathrm{ha}(51 \%)$.
\end{abstract}

Keywords: Sea Water Intrusion, Groundwater, Surabaya City 


\section{PENDAHULUAN}

Permasalahan pokok sumber daya air yang terjadi di Indonesia adalah keragaman sistem akuifer, posisi dan penyebaran penyusupan/intrusi air laut. Intrusi air laut dapat terjadi secara alami maupun oleh karena adanya pengambilan air tanah secara berlebih (over exploitation) untuk kebutuhan domestik dan untuk keperluan industri. Pengambilan air tanah secara berlebih akan menyebabkan persediaan air tanah pada lapisan akuifer semakin berkurang. Berkurangnya persedian air tanah pada lapisan akuifer dapat menyebabkan terjadinya intrusi air laut, dimana air laut tersebut akan menyusup ke zona air tanah. Jika hal ini terjadi, maka kualitas air di wilayah tersebut akan menurun dikarenakan tingginya kadar klorida yang menyebabkan air akan berasa asin atau payau.

Adanya kenaikan permukaan air laut, penurunan permukaan tanah dan pengambilan air tanah yang dilakukan secara berlebihan akan memicu terjadinya intrusi air laut. Pengambilan air tanah yang berlebihan menyebabkan banyaknya ruang kosong di dalam akuifer dan mengakibatkan tinggi muka air tanah lebih rendah dari pada permukaan air laut, perbedaan tinggi permukaaan air tanah dengan permukaan air laut ini menyebabkan air laut yang mengandung unsur garam seperti klorida $(\mathrm{Cl})$ merembes ke dalam air tanah sehingga menimbulkan pencemaran air tanah. Pencemaran air tanah (SNI 19-6728.1-2002) adalah masuknya unsur satuan, komponen fisika, kimia atau biologi ke dalam air bawah tanah dan/atau berubahnya tatanan air bawah tanah oleh kegiatan manusia atau oleh proses alami yang mengakibatkan mutu air bawah tanah turun sampai ke tingkat tertentu, sehingga tidak dapat dimanfaatkan sesuai dengan peruntukkannya.

Surabaya merupakan kota terbesar kedua di Indonesia dan merupakan daerah kawasan pesisir pantai. Tentunya kawasan Surabaya sangat intensif dimanfaatkan untuk kegiatan manusia, terutama yang tinggal di kawasan pesisir Surabaya, seperti: pusat pemerintahan, pemukiman, industri, pelabuhan, pertambakan dan pariwisata. Hal ini akan berakibat pada peningkatan kebutuhan akan lahan dan prasarana lainya, sehingga akan timbul masalah- masalah baru di kawasan pesisir Surabaya, seperti: erosi pantai yang menyebabkan majunya garis pantai, kenaikan muka air laut serta intrusi air laut yang akan mempengaruhi air tanah.

Intrusi air laut ditandai dengan tingginya salinitas/kadar khlorida $(\mathrm{Cl})$ dalam air. Hasil studi penelitian yang dilakukan oleh daerah rawan bencana kegeologian yang dilakukan oleh Dinas ESDM Propinsi Jawa Timur Tahun 2007, menunjukkan bahwa hampir seluruh titik sampel yang diambil dari air sumur gali, kandungan khloridanya cukup tinggi. Pada titik tertentu, kandungan khlorida sudah sangat tinggi, hingga mencapai $4000 \mathrm{mg} / \mathrm{L}$. Selain itu masih banyak pula titik sampel yang kandungan khloridanya melebihi $1000 \mathrm{mg} / \mathrm{L}$ yang umumnya pada wilayah-wilayah yang berhadapan dengan pesisir pantai.

Penggambaran kondisi sebaran wilayah terintrusi air laut di Kota Surabaya perlu dilakukan, sebagai penyediaan basis data dalam rangka pengelolaan sumber daya air tanah yang berkelanjutan.

\section{METODE PENELITIAN}

\section{1. Tempat dan Waktu Penelitian}

Penelitian ini dilakukan di Kota Surabaya, dengan melakukan pengambilan sampel sebanyak 28 sampel. Sampel diperoleh dengan mengambil sampel air pada sumur gali (air tanah dangkal). Sampel air yang telah didapat, selanjutnya dilakukan uji laboratorium untuk mengetahui konsentrasi klorida $(\mathrm{Cl})$ pada air tanah.

Parameter kualitas air untuk mengindikasikan telah terjadi intrusi air laut terhadap air adalah tingkat konsentrasi klorida $(\mathrm{Cl})$, dimana parameter tersebut merupakan salah satu unsur kimia yang berasal dari air laut yang terkandung dalam senyawa garam. Klasifikasi tingkat kegaraman air tanah disajikan pada Tabel 1 . 
Tabel 1. Klasifikasi Tingkat Kegaraman Air Tanah

\begin{tabular}{cc}
\hline Kelas Kualitas & Kadar Cl (mg/l) \\
\hline Tawar & $<250$ \\
Payau & $250-650$ \\
Asin & $>650$ \\
\hline
\end{tabular}

Sumber: Adi dan Setiawan (2010)

\section{2. Prosedur Pengambilan Sampel}

Pengambilan sampel air tanah dilakukan dengan melakukan pengambilan sampel air di sumur gali. Selain dilakukan pengambilan sampel air, juga dilakukan pencatatan koordinat lokasi sumur dengan menggunakan GPS dan pengukuran tinggi muka air tanah dangkal untuk mengetahui elevasinya.

Untuk mengetahui elevasi muka air tanah (MAT) dilakukan dengan pengukuran kedalaman muka air tanah. Pengukuran kedalaman muka air tanah dilakukan pada sumur gali warga. Skema pengukuran elevasi MAT pada sumur gali tersaji pada Gambar 1.

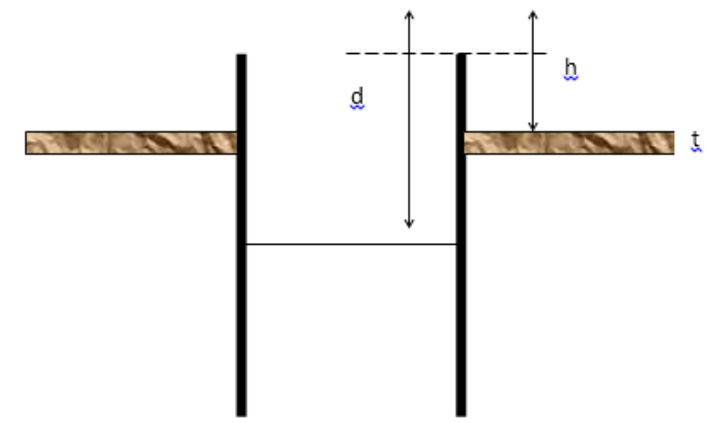

Gambar 1. Skema pengukuran elevasi MAT pada sumur gali

\section{3. Analisis Data}

Data yang didapatkan, selanjutnya dilakukan analinisis. Analisis data yang digunakan pada penelitian ini menggunakan analisis spasial. Prahasta (2009) menjelaskan, analisis spasial merupakan suatu teknik atau proses yang melibatkan sejumlah hitungan dan evaluasi logika yang dilakukan dalam rangka mencari atau menemukan potensi hubungan atau pola yang terdapat diantara unsur geografis.

\section{GAMBARAN UMUM LOKASI PENELITIAN}

\subsection{Kondisi Geografis dan Wilayah Administrasi}

Penelitian ini dilakukan di Kota Surabaya. Secara astronomi, Kota Surabaya berada pada koordinat antara $7^{\circ} 21^{\prime}$ Lintang Selatan dan $112^{\circ} 36^{\prime}-112^{\circ}$ 54' Bujur Timur, dengan batas administrasi sebagai berikut:

- Sebelah Utara : Selat Madura

- Sebelah Timur : Selat Madura

- Sebelah Selatan : Kabupaten Sidoarjo

- Sebelah Barat : Kabupaten Gresik

Wilayah Kota Surabaya memiliki luas wilayah sebesar $\pm 326,36 \mathrm{Km}^{2}$ yang terbagi dalam 31 Kecamatan dan 163 Kelurahan. Surabaya terbagi dalam 5 wilayah regional yaitu Surabaya Timur, Barat, Utara, Selatan dan Surabaya Pusat.

\subsection{Topografi Kota Surabaya}

Berdasarkan Laporan Data dan Informasi CAT Kota Surabaya (BLH Kota Surabaya, 2013) disebutkan bahwa, topografi regional Kota Surabaya memiliki elevasi antara $0-30 \mathrm{~m}$ di atas permukaan laut (mdpl). Wilayah dengan elevasi rendah berada pada daerah pesisir pantai yang memiliki elevasi berkisar antara $0-3 \mathrm{mdpl}$, bahkan sebagian lebih rendah dari rata-rata muka air laut (mean sea level), hal ini dapat dilihat dari munculnya genangan air pada saat pasang.

Wilayah Kota Surabaya yang memiliki elevasi antara $0-10 \mathrm{mdpl}$ menempati lahan seluas $25.919,04$ ha $(80,72 \%$ dari luas wilayah Kota Surabaya) menyebar di bagian timur, utara, selatan, dan pusat. Pada wilayah kota lainnya yang memiliki elevasi berkisar antara $10-20$ mdpl $(12,53 \%)$ dan di atas 20 mdpl $(6,76 \%)$ umumnya terdapat pada bagian barat dan selatan Kota Surabaya yaitu di Kecamatan Sawahan, Karangpilang, Benowo, Lakarsantri, dan Tandes. 


\subsection{Geomorfologi Kota Surabaya}

Berdasarkan data yang diperoleh dari Laporan Data dan Informasi CAT Kota Surabaya (BLH Kota Surabaya, 2013), satuan geomorfologi Kota Surabaya dapat dibagi menjadi 2 (dua), yaitu:

1. Satuan Dataran

Satuan dataran di wilayah Kota Surabaya meliputi Kecamatan Pakal, Benowo, Asemrowo, Lakarsantri, Wiyung, Jambangan, Gayungan, Trenggilismejoyo, Wonocolo, Wonokromo, Tegalsari, Gubeng, Genteng, Bubutan, Krembangan, Pabeancantikan, Semampir, Kenjeran, Simoketo, Bulak, Tambaksari, Mulyorejo,Rungkut, Sukolilo, dan Gununganyar. Litologi penyusun satuan ini didominasi endapan aluvium. Jenis tanah yang dijumpai berupa Aluvial Hidromorf, Aluvial Kelabu dan Aluvial Kelabu Tua. Berdasarkan litologi penyusun tersebut,keterdapatan air tanah dapat dijumpai secara meluas. Penggunaan lahan pada satuan morfologi ini umumnya daerah persawahan, tegalan, permukiman, pusat perdagangan, dan tambak. Wilayah dataran pada umumnya merupakan daerah lepasan air tanah.

2. Satuan Dataran Bergelombang Lemah Yang termasuk wilayah satuan ini meliputi Kecamatan Sukomenanggal, Sambikerep, Sawahan, Dukuhpakis dan Karangpilang. Litologi penyusun satuan ini adalah batu lempung bersisipkan batupasir dan setempatsetempat konglomerat, batupasir tufan berlapis baik bersisipan konglomerat dan batulempung, serta batulempung berwarna biru. Berdasarkan litologi di atas lapisan yang dapat berfungsi sebagai akuifer adalah batupasir, batupasir tufan dan konglomerat. Keterdapatan air tanah akan dijumpai secara meluas dan setempat-setempat yang merupakan akuifer produktif. Jenis tanah yang dijumpai berupa Grumosol Kelabu Tua, Aluvial Kelabu dan Aluvial Kelabu Tua. Wilayah dataran bergelombang lemah dapat berfungsi sebagai wilayah daerah isian air tanah untuk wilayah disekitarnya, namun secara regional dapat juga merupakan daerah lepasan air tanah.

\subsection{Geologi Kota Surabaya}

Berdasarkan Peta Geologi Lembar SurabayaSepulu dan Peta Geologi Teknik Lembar Surabata-Sedati pada Laporan Data dan Informasi CAT Kota Surabaya (BLH Kota Surabaya, 2015), wilayah Kota Surabaya terbagi menjadi:

1. Dataran Aluvium

Dataran aluvium ini memiliki kandungan kerakal, kerikil, lempung, dan setempat pecahan cangkang fosil. Wilayah di Surabaya yang berada pada dataran ini, meliputi wilayah-wilayah Surabaya bagian timur seperti Kecamatan Rungkut, Mulyorejo, Bulak, Kenjeran, serta wilayah Surabaya Utara, seperti Kecamatan Semampir, Pabeancantikan, Krembangan, Asemrowo dan Benowo.

2. Formasi Kabuh

Formasi ini terdiri dari batu lempung bersisipkan batupasir dan setempat-setempat konglomerat. Fosil jarang dijumpai. Formasi ini berumur Pleistosen. Tanah hasil pelapukan formasi ini berwarna abu-abu kehitaman, lunak - teguh, plastisitas tinggi, permeabilitas rendah. Ketebalan soil $4-9,5$ m. Penyebaran batuan formasi ini terdapat pada sebagian wilayah Kecamatan Rungkut, Wonocolo, Tenggilis Mejoyo, Wiyung, Karangpilang, Lakarsantri, Tandes, Sukomanunggal, Benowo, dan Dukuh Pakis.

3. Formasi Pucangan

Formasi ini terdiri dari batupasir tufan; berlapis baik, bersisipan konglomerat dan batulempung; kaya akan fosil moluska dan plangton; bagian atas, terdiri dari batupasir tufan berlapis baik; umumnya berstruktur arian dan silang-siur. Formasi ini berumur Pliosen - Pleistosen. Tanah hasil pelapukan formasi ini berwarna coklat kekuningan, teguh - kaku, plastisitas sedang, permeabilitas rendah - sedang. Pasir berbutir halus - sedang. Ketebalan soil 3,5-6,5 m. 
Wilayah penelitian menempati morfologi berelief halus, kemiringan $5-10 \%$. Kedalaman muka air tanah bebas sedang dalam. Penyebarannya terutama di sebagian Kecamatan Dukuh Pakis, Sawahan, Sukomanunggal, Tandes, Benowo, Wiyung, Lakarsantri, Karangpilang, dan Gubeng.

\section{Formasi Lidah}

Formasi ini terdiri dari batulempung berwarna biru, setempat kehitaman; liat, pejal dan bila kering keras. Formasi ini miskin akan fosil, setempat dijumpai lensa tipis batulempung pasiran yang mengandung fosil plankton. Tanah hasil pelapukan formasi ini berwarna coklat keabuan, konsistensi teguh - kaku, plastisitas tinggi permeabilitas rendah - kedap air. Ketebalan soil 3,5m hingga lebih dari $10 \mathrm{~m}$. Pada wilayah penelitian satuan ini terletak pada perbukitan berelief halus, dengan kemiringan $5-10 \%$. Kedalaman muka air tanah bebas sangat dalam dan terbatas, terutama pada lembah antar bukit. Penyebarannya sebagian di Kecamatan Wonokromo, Sawahan, Dukuh Pakis, Lakarsantri, Karangpilang, dan Wiyung.

\subsection{Geohidrologi Kota Surabaya}

Sub Cekungan Air Tanah Surabaya merupakan bagian dari Cekungan Air Tanah (CAT) Brantas dan Cekungan Air Tanah Surabaya Lamongan. Sistem akuifer yang berkembang di sub CAT ini dikelompokkan menjadi 2 (dua) jenis, yaitu akuifer dengan aliran melalui ruang antar butir dan aliran melalui celah dan sarang (BLH Kota Surabaya, 2015).

Produktifitas akuifer yang ada di lokasi penelitian dibedakan menjadi 4 (empat) tipe, yaitu produktif kecil setempat berarti, produktif kecil dengan penyebaran luas, produktif sedang dengan penyebaran luas, dan produktif tinggi akuifer lebih dalam. Keterusan lapisan batuan di lokasi penelitian dikelompokkan menjadi rendah dan sedang. Debit rata-rata aliran air tanah pada daerah penelitian dikelompokkan menjadi 3, yaitu besar (>10 liter/detik), sedang $(2-10$ liter/detik) dan kecil ( $<2$ liter/detik).

\section{HASIL DAN PEMBAHASAN}

\subsection{Kontur Elevasi dan Arah Aliran Air Tanah Kota Surabaya}

Penggambaran kontur elevasi muka air tanah (MAT) menggunakan data elevasi MAT, untuk selanjutnya dari Peta Kontur Elevasi MATdapat ditentukan arah aliran air tanahnya.

Penentuan arah aliran air tanah dengan menggunakan metode Three Point Problem (Todd, 1959), yaitu dengan menghubungkan titik-titik yang memiliki nilai elevasi yang sama, sehingga menjadi garis kontur. Dari garis kontur tersebut, selanjutnya ditarik garis tegak lurus, sehingga dapat diketahui arah aliran air tanahnya. Arah aliran air tanah ditentukan melalui peta kontur muka freatik, karena arah aliran air tanah akan memotong tegak lurus $\left(90^{\circ}\right)$ kontur air tanahnya.

Penggambaran Peta Kontur Elevasi MAT dilakukan dengan interval 5 meter, sehingga dapat dilihat pengelompokkan setiap wilayahnya, yaitu pada elevasi 15, 10, 5 dan 1 mdpl (meter di atas permukaan laut). Daerahdaerah dengan rata-rata elevasi MAT $15 \mathrm{mdpl}$ meliputi daerah di Kecamatan Sambikerep, Lakarsantri, dan Dukuhpakis. Secara administrasi, daerah-daerah ini merupakan daerah yang berada di wilayah Surabaya Barat. Berdasarkan peta topografi, daerah-daerah ini merupakan daerah dengan elevasi yang lebih tinggi dibandingkan dengan daerah lain di Kota Surabaya. Freeze dan Cherry (1979) menyatakan bahwa, muka air tanah bebas dan arah aliran air tanah bebas dipengaruhi oleh topografi. Semakin tinggi elevasi suatu tempat, maka semakin tinggi pula muka air tanah bebasnya. Berdasarkan pemanfaatan lahan, daerah ini sebagian besar dimanfaatkan untuk kepentingan permukiman. Area persawahan dan tegalan juga masih banyak ditemukan di daerah ini, sehingga daerah yang berpotensi sebagai daerah resapan air masih banyak ditemukan di sekitar wilayah ini. Berdasarkan Peraturan Daerah Kota Surabaya 
No. 12 Tahun 2014, wilayah-wilayah di Kecamatan Wiyung, Kecamatan Karang Pilang dan Kecamatan Lakarsantri merupakan wilayah yang ditetapkan sebagai fungsi pusat lingkungan. Fungsi utama pusat lingkungan pada daerah ini meliputi permukiman, pendidikan, industri dan lindung terhadap alam. Pada fungsi utama pusat lingkungan, seharusnya lahan dimanfaatkan sepenuhnya untuk keperluan konsverasi lingkungan.

Daerah dengan elevasi MAT 10 mdpl berdasarkan Peta Kontur elevasi MAT ditemukan di sebagian daerah di Kecamatan Karangpilang. Kecamatan Karangpilang termasuk dalam wilayah Surabaya Selatan. Kecamatan Karangpilang secara administrasi terbagi dalam 4 kelurahan dan berbatasan langsung dengan Kabupaten Sidoarjo. Berdasarkan peta tata guna lahan, pola pemanfaatan lahan di wilayah kecamatan ini didominasi untuk kegiatan industri, sedangkan sisanya dimanfaatkan untuk permukiman.

Elevasi MAT 5 mdpl ditemukan di beberapa wilayah, seperti Kecamatan Wiyung, Kecamatan Wonokromo, dan Kecamatan Sukomanunggal. Secara pembagian wilayah, Kecamatan Wiyung dan Kecamatan Wonokromo masuk dalam wilayah Surabaya Selatan. Pola pemanfaatan lahan di dua kecamatan ini didominasi untuk wilayah permukiman dan RTH, serta Tegalan dalam presentase yang sangat terbatas. Wilayah lain dengan elevasi MAT 5 mdpl ditemukan di wilayah Kecamatan Sukomanunggal. Kecamatan Sukomanunggal masuk dalam wilayah Surabaya Barat, dan terbagi menjadi 6 kelurahan. Sebagian besar wilayah kecamatan ini dimanfaatkan untuk area permukiman. Pemanfaatan lain untuk tegalan, ditemukan dalam persentase rendah.

Sebagian besar wilayah di Kota Surabaya memiliki elevasi MAT kurang dari 3 meter, yaitu antara $0-3$ meter. Wilayah dengan elevasi MAT 0 - 3 mdpl menyebar di hampir seluruh wilayah di Kota Surabaya, khususnya di wilayah Surabaya Utara, Timur Pusat dan sebagian wilayah Surabaya Barat dan Surabaya Selatan. Pemanfaatan lahan di wilayah dengan elevasi
MAT 0 - 3 mdpl didominasi oleh permukiman, industri, perdagangan dan jasa, pertambakan serta kawasan mangrove.

Aliran air tanah dapat diterapkan dengan Hukum Darcy yang menyatakan bahwa laju aliran melalui media sarang berbanding lurus dengan head loss. Air tanah mengalir dari potential head tinggi menuju potential head yang lebih rendah. Antara titik-titik dengan energi potensial sama tidak terdapat pengaliran air tanah. Garis khayal yang menghubungkan titik-titik yang sama energi potensialnya disebut garis kontur muka air tanah atau garis isohypse. Sepanjang garis kontur tersebut tidak terdapat aliran air tanah, karena arah aliran air tanah tegak lurus dengan garis kontur (Usmar dkk, 2006).

Berdasarkan Peta Kontur Elevasi MAT dan Arah Aliran Air Tanah, arah aliran air tanah di Kota Surabaya secara umum dimulai dari wilayah dengan kontur yang tinggi (wilayah Surabaya Barat meliputi Kecamatan Lakarsantri, Dukuhpakis dan Sambikerep) menuju ke wilayah dengan kontur yang lebih rendah, sehingga arah aliran air tanah di Kota Surabaya mengikuti kontur topografinya. Semakin tinggi suatu wilayah, maka akan memiliki potential head yang lebih tinggi. Hal ini sesuai dengan konsep Hukum Darcy yang menyatakan bahwa air tanah mengalir dari potential head yang lebih tinggi menuju potential head yang lebih rendah.

Sub-sistem arah aliran air tanah di Kota Surabaya terbagi menjadi III. Sub-sistem tersebut antara lain adalah arah aliran yang berawal dari wilayah barat menuju ke arah timur, barat menuju ke arah utara dan sebagian kecil dari barat menuju ke arah selatan.

Sub-sistem arah aliran air tanah I, dimulai dari wilayah Surabaya Barat menuju ke arah timur yang meliputi berbagai daerah di Kecamatan Karangpilang, Gayungan, Jambangan, Wonocolo, Tenggilismejoyo, Gununganyar, Rungkut, Sukolilo, Tegalsari, Gubeng, Mulyorejo, Genteng, Tambaksari, Simokerto, Bulak, dan Kenjeran. Arah aliran tanah II dimulai dari wilayah Surabaya Barat menuju ke arah 
utara yang meliputi daerah-daerah di Kecamatan Pakal, Tandes, Sawahan, Bubutan, Asemrowo, Benowo, Krembangan, Pabeancantikan, dan Semampir, sedangkan arah aliran air tanah III, dimulai dari wilayah barat dan menuju ke arah selatan menuju wilayah Kabupaten Sidoarjo.

Arah aliran air tanah di Kota Surabaya dikontrol oleh topografi wilayah. Hal ini ditunjukkan dari keseluruhan sub-sistem arah aliran air tanah yang dimulai dari wilayah dengan elevasi tinggi menuju ke wilayah dengan elevasi rendah.

\subsection{Kawasan Terintrusi Air Laut Kota Surabaya}

Penurunan kondisi kualitas air dapat terjadi karena adanya intrusi air laut. Intrusi air laut akan menyebabkan tingginya kadar ion $\mathrm{Cl}^{-}$(klorida) atau kadar garam pada air. Putranto dan Kusuma (2009) menjelaskan, intrusi air laut adalah masuknya atau menyusupnya air laut kedalam pori-pori batuan dan mencemari air tanah yang terkandung didalamnya sehingga menyebabkan air tanah berubah menjadi air payau atau bahkan air asin. Kebutuhan air yang selalu meningkat sering membuat orang lupa bahwa daya dukung alam ada batasnya dalam memenuhi kebutuhan air (Santoso dkk, 2013). Dalam keadaan alami air tanah tawar mengalir ke lautan lewat akuiferakuifer di daerah pantai yang berhubungan dengan lautan pada pantai yang menjorok ke laut. Tetapi karena meningkatnya kebutuhan akan air tawar, maka aliran air tanah tawar ke arah laut telah menurun. Bahkan sebaliknya, air laut akan mengalir masuk ke dalam sumur-sumur di daratan, sehingga air menjadi tidak berguna, karena akuifer telah tercemar oleh air asin.

Beberapa wilayah di Indonesia mempunyai air tanah dengan kadar garam yang tinggi. Kadar garam yang tinggi dalam air tanah dapat terjadi secara alamiah atau akibat aktivitas manusia. Peningkatan populasi dan pertumbuhan industri telah mendorong meningkatnya permintaan untuk sumber daya alam, terutama air (Wahyudi, dkk., 2014). Apabila pengambilan air tanah dilakukan secara berlebih maka akan menyebabkan cadangan air tanah berkurang dan memicu air laut menyusup ke dalam akuifer.

Penelitian yang dilakukan oleh Purnomo (2013) di wilayah pesisir Surabaya Timur menunjukkan bahwa air tanah di wilayah Surabaya bagian timur telah tercemar berat oleh air laut, sehingga air tanah memiliki nilai salinitas yang tinggi dan berasa asin dan tidak dapat digunakan untuk keperluan air minum.

Kawasan pantai adalah kawasan yang secara topografi merupakan dataran rendah. Secara geologi, batuan penyusun dataran umumnya berupa endapan alluvial yang terdiri dari lempung, pasir, dan kerikil dari pengangkutan dan erosi batuan di bagian hulu sungai. Umumnya batuan di dataran bersifat kurang kompak, sehingga potensi air tanahnya cukup baik. Akuifer di dataran pantai yang baik umumnya berupa akuifer tertekan, tetapi akuifer bebas pun dapat menjadi sumber air tanah yang baik terutama pada daerah-daerah pematang pantai. Intrusi air laut di daerah pantai merupakan suatu proses penyusupan air asin dari laut ke dalam air tanah tawar di daratan. Aktifitas manusia dalam penggunaan air di Kota Surabaya mempengaruhi kelestarian alam yang dapat menimbulkan dampak lingkungan. Bentuk aktifitas manusia yang berdampak pada sumberdaya air terutama intrusi air laut adalah pemompaan air tanah melalui sumur pompa/produksi yang berlebihan dan keberadaannya dekat dengan pantai. Tabel 2 . menyajikan hasil analisis ion klorida pada sampel air. 
Tabel 2. Hasil Analisis Laboratorium Unsur Klorida Pada Sampel Air Tanah

\begin{tabular}{|c|c|c|c|c|c|c|}
\hline \multirow[t]{2}{*}{ No. } & \multicolumn{2}{|c|}{ Koordinat Lokasi } & \multirow{2}{*}{$\frac{\mathrm{Cl}^{-}}{(\mathrm{mg} / \mathrm{L})}$} & \multirow{2}{*}{ Keterangan } & \multirow{2}{*}{ Kecamatan } & \multirow{2}{*}{ Kelurahan } \\
\hline & $\mathbf{X}$ & $\mathbf{Y}$ & & & & \\
\hline 1 & 686041 & 9187598 & 228 & Tawar & Karangpilang & Warunggunung \\
\hline 2 & 691516 & 9192773 & 60 & Tawar & Wonokromo & Darmo \\
\hline 3 & 694407 & 9191803 & 96 & Tawar & Tenggilis Mejoyo & Panjang Jiwo \\
\hline 4 & 699396 & 9191665 & 640 & Payau & Rungkut & Wonorejo \\
\hline 5 & 692350 & 9197092 & 100 & Tawar & Genteng & Ketabang \\
\hline 6 & 691480 & 9200551 & 136 & Tawar & Krembangan & Krembangan Selatan \\
\hline 7 & 679470 & 9204054 & 696 & Asin & Pakal & Tambakrejo \\
\hline 8 & 675839 & 9202046 & 180 & Tawar & Pakal & Babatjerawat \\
\hline 9 & 699652 & 9193333 & 9300 & Asin & Sukolilo & Keputih \\
\hline 10 & 689833 & 9187987 & 60 & Tawar & Gayungan & Menanggal \\
\hline 11 & 681342 & 9192149 & 284 & Payau & Lakarsantri & Jeruk \\
\hline 12 & 680843 & 9196039 & 160 & Tawar & Sambi Kerep & Made Utara \\
\hline 13 & 679487 & 9197398 & 68 & Tawar & Pakal & Babatjerawat \\
\hline 14 & 686943 & 9194982 & 80 & Tawar & Dukuhpakis & Pradah Kalikendal \\
\hline 15 & 695809 & 9198709 & 192 & Tawar & Tambaksari & Gading \\
\hline 16 & 684038 & 9190017 & 256 & Payau & Wiyung & Sumurwelut \\
\hline 17 & 692858 & 9189797 & 192 & Tawar & Tenggilis Mejoyo & Kendangsari \\
\hline 18 & 698840 & 9189994 & 7000 & Asin & Rungkut & Medokan Ayu \\
\hline 19 & 688960 & 9193358 & 84 & Tawar & Dukuhpakis & Dukuhpakis \\
\hline 20 & 692423 & 9197038 & 40 & Tawar & Genteng & Ketabang \\
\hline 21 & 695576 & 9201399 & 56 & Tawar & Kenjeran & Tanah Kali Kedinding \\
\hline 22 & 684334 & 9194576 & 92 & Tawar & Sambikerep & Lontar \\
\hline 23 & 684742 & 9197905 & 948 & Asin & Tandes & Buntaran \\
\hline 24 & 685850 & 9200585 & 204 & Tawar & Asemrowo & Greges \\
\hline 25 & 687958 & 9190321 & 136 & Tawar & Karangpilang & Kedurus \\
\hline 26 & 698991 & 9195597 & 528 & Payau & Mulyorejo & Mulyorejo \\
\hline 27 & 688623 & 9200492 & 180 & Tawar & Krembangan & Morokrembangan \\
\hline 28 & 678472 & 9200913 & 364 & Tawar & Pakal & Benowo \\
\hline \multicolumn{2}{|c|}{ Sumber } & $\begin{array}{l}\text { engambilat } \\
\text { Iasil Analis }\end{array}$ & $\begin{array}{l}\text { ampel } 1 \\
\text { Caborato } \\
\text { (a) }\end{array}$ & -21 Oktober & $\begin{array}{l}15 \\
\text { ir, FTSP-IT }\end{array}$ & \\
\hline
\end{tabular}

Berdasarkan hasil analisis laboratorium (Tabel 2), terlihat bahwa 20 sampel air menunjukkan dalam kualitas yang baik dengan kondisi air tawar $\left(\mathrm{Cl}^{-}<250 \mathrm{mg} / \mathrm{l}\right)$. Kondisi tersebut menunjukkan sebagian besar air tanah dangkal di Kota Surabaya dalam kondisi tawar. Kondisi air dengan kualitas payau ditemukan pada 4 sampel, sedangkan air dengan kualitas air asin ditemukan pada 4 sampel. Hal ini menunjukkan bahwa intrusi air laut telah terjadi di beberapa lokasi di Surabaya. Nilai klorida yang didapat selanjutnya di-plot atau diproses guna menghasilkan peta sebaran tingkat intrusi air laut. Proses pembuatan peta sebaran tingkat intrusi air laut melalui proses interpolasi menggunakan Program ArcGIS 10.3 dengan Model Kriging. Peta Kawasan Terintrusi Air Laut Kota Surabaya tersaji pada Gambar 2. 


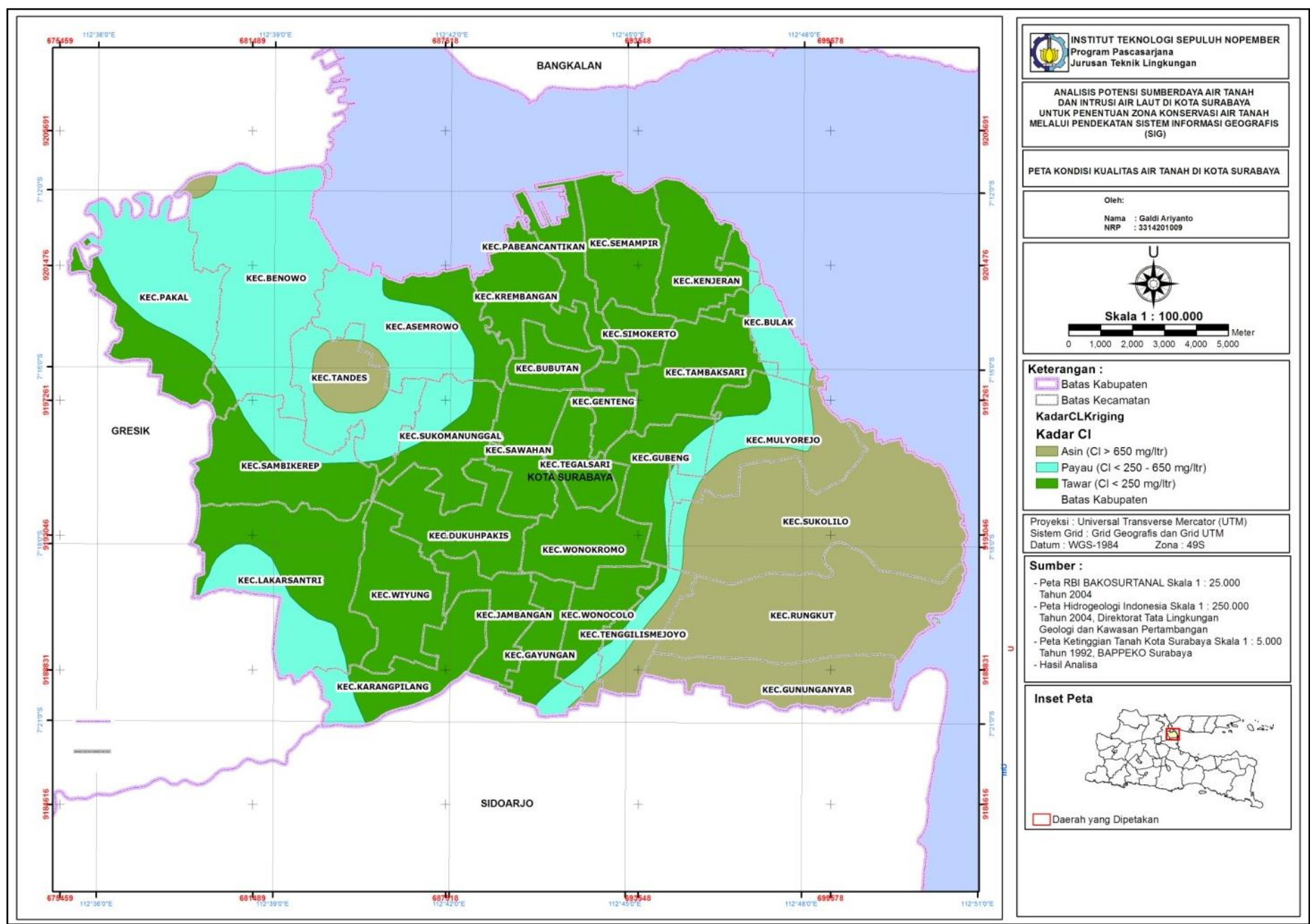

Gambar 2. Peta Kawasan Terintrusi Air Laut Kota Surabaya 
Hasil Studi atau Penelitian Daerah Rawan Bencana Kegeologian yang dilakukan oleh Dinas ESDM Propinsi Jawa Timur Tahun 2007, menunjukkan bahwa hampir seluruh titik sampel yang diambil dari air sumur gali, kandungan kloridanya cukup tinggi. Pada titik tertentu kandungan klorida sudah sangat tinggi. Selain itu masih banyak pula sampel yang kandungan kloridanya melebihi $1000 \mathrm{mg} / \mathrm{L}$ yang umumnya pada wilayah-wilayah yang berhadapan dengan pesisir pantai.

Berdasarkan Laporan Data dan Informasi CAT Kota Surabaya (BLH Kota Surabaya 2013) menunjukkan bahwa $47 \%$ dari wilayah di Kota Surabaya kondisi kualitas air tanahnya berasa asin, $30 \%$ payau dan hanya $23 \%$ saja dalam kondisi tawar. Wilayah yang terintrusi air laut terjadi di sepanjang pesisir pantai timur dan utara Kota Surabaya.

Berdasarkan Peta Intrusi Air Laut Kota Surabaya Tahun 2015 (Gambar 1), intrusi air laut di terjadi di hampir sepanjang wilayah pantai timur Surabaya, selain itu juga terjadi di Kecamatan Tandes. Wilayah pantai timur Surabaya merupakan wilayah yang cepat berkembang dalam penggunaan lahan sebagai permukiman. Purnomo (2013) menyebutkan, pesisir timur Surabaya daerah yang perkembangannya cukup pesat dalam penggunaan lahan sebagai permukiman maupun industri. Dengan perkembangan itu, tentunya kebutuhan akan air bersih akan bertambah. Tingginya pengambilan air, akan memicu terjadinya intrusi air laut. Wilayah di pesisir timur Surabaya yang telah terintrusi air laut meliputi Kecamatan Gununganyar, Rungkut dan Sukolilo. Wilayah yang terintrusi air laut tidak selamanya memberikan dampak negatif kehidupan manusia. Kondisi air tanah yang berasa asin memang tidak mendukung wilayah tersebut untuk dijadikan sebagai wilayah permukiman, namun demikian dapat dimanfaatkan untuk kegiatan lain, seperti budidaya perikanan air payau, tambak garam, dan sebagainya. Penelitian yang dilakukan oleh Setiyono, dkk. (2013) menunjukkan bahwa, wilayah pesisir timur Surabaya berpotensi untuk dijadikan wilayah budidaya perikanan air payau.
Hal ini didukung oleh kondisi kualitas air tanah yang relatif mendekati kualitas air laut, terlebih pada wilayah yang dekat wilayah pantai.

Selain di pesisir timur Surabaya, intrusi air laut juga ditemukan terjadi di wilayah Kecamatan Tandes. Hal ini ditunjukkan oleh hasil analisis laboratorium bahwa kandungan klorida pada air sebesar $948 \mathrm{mg} / \mathrm{L}$. Lokasi pengambilan sampel berada di dalam area kawasan industri Margomulyo. Kawasan ini merupakan kawasan industri yang dimungkinkan banyak menggunakan air tanah, khususnya untuk keperluan industri. Intrusi air laut, salah satunya dapat dipicu karena adanya pemanfaatan air sumur secara berlebihan, selain itu juga karena telah terjadinya penurunan muka tanah (land subsidence). Hendrayana dan Prakasa (2008) menjelaskan, terjadinya amblesan (penurunan) muka tanah, dapat memicu terjadinya intrusi air laut.

Berdasarkan Peta Kawasan Terintrusi Air Laut Kota Surabaya (Gambar 1), terdapat satu lokasi yang wilayahnya terintrusi air, yaitu di wilayah Kecamatan Tandes, dibandingkan wilayah di sekitarnya, hanya di titik ini saja yang kondisi kualitas airnya asin. Kondisi ini dimungkinkan karena adanya air laut yang terjebak dan tersimpan dalam tanah. Wilayah di Kota Surabaya sebagian besar berupa dataran aluvium. Dataran aluvium memiliki kandungan kerakal, kerikil, lempung, dan setempat pecahan cangkang fosil. Dataran aluvium, dapat terbentuk dari endapan lumpur yang dibawa melalui sungai-sungai atau dari sedimentasi pada wilayah pantai. Wilayah Surabaya yang sebagian besar berupa dataran aluvium, sangat memungkinkan adanya air laut yang terjebak dalam tanah pada saat proses terjadinya daratan.

\section{KESIMPULAN}

Berdasarkan hasil analisis data, diketahui bahwa $23 \%$ wilayah di Kota Surabaya kondisi kualitas air tanahnya asin, $26 \%$ payau dan sisanya pada kondisi tawar. Dibandingkan dengan tahun 2013, wilayah yang terintrusi air laut di Kota Surabaya mengalami penurunan, sehingga menunjukkan 
bahwa telah terjadi peningkatan kondisi kualitas air tanah di Kota Surabaya.

\section{DAFTAR PUSTAKA}

Badan Lingkungan Hidup (BLH) Kota Surabaya. 2013. Data dan Informasi Cekungan Air Tanah Kota Surabaya. Surabaya.

Freeze, R.A. and Cherry, J.A. 1979. Groundwater. Hemel Hempstead: Prentice-Hall International.

Juanda, D.P., Budidharma, D., Irawan, D.E., Anggayana, K., 2004. "Pendugaan Aliran Air dari Danau Aneuk Laot ke Mata Air Zwembat melalui Akifer Volkanik berdasarkan Perunutan Isotop Stabil (Deuterium dan Oksigen-18), Kabupaten Sabang, D.I.- Nangro Aceh Darussalam". Jurnal Teknologi Mineral Vol XI, No. 2/2004, hal: 88-101.

Herlambang, A., dan Indriatmoko, R.H., 2005. Pendugaan Potensi Air Tanah dengan Metode Resistivitas Dua Dimensi Di Wilayah Pesisir Untuk Perencanaan Bangunan Air Bersih di Kabupaten Pasir Kalimantan Timur. Jurnal Air Indonesia. Vol. 1 No. 3.

Prahasta, E., 2009. Sistem Informasi Geografis: "Konsep-konsep Dasar (Perspektif Geodesi \& Geomatika)". Penerbit Informatika, Bandung.
Putranto, T., dan Kusuma, K.I., 2009. Permasalahan Air tanah Pada Daerah Urban. Jurnal Teknik, Vol. 30 No. 1.

Purnomo, N.A., Wahyudi, dan Suntoyo. 2013. Studi Pengaruh Air Laut Terhadap Air Tanah di Wilayah Pesisir Surabaya Timur. Jurnal Teknik POMITS Vol. 1, No. 1, (2013) 1 - 6 .

Santoso, T., Priyantari, N., dan Hiskiawan, P., 2013. Pendugaan Intrusi Air Laut Dengan Metode Geolistrik Resistivitas 1D di Pantai Payangan Desa Sumberejo Jember. Jurnal BERKALA SAINSTEK 2013, I (1): 17-19.

Setiyono, A., Wahyudi, dan Suntoyo, 2013, Studi Potensi Air Tanah di Pesisir Surabaya Timur Untuk Budidaya Perikanan Air Payau. Jurnal Teknik POMITS (2013) 1 -5 .

Wahyudi, A., Setyono, dan Jayanthi, O.W.,. 2014. Studi Kualitas Dan Potensi Pemanfaatan Airtanah Dangkal Di Pesisir Surabaya Timur. Eksplorium. Volume 35 No. 1, Mei 2014: 43 - 56.

Wibowo, M., 2001. Potensi Sumberdaya Air Tanah di Surabaya Berdasarkan Survei Geolistrik Tahanan Jenis. Jurnal Teknologi Lingkungan, Vol.2, No. 1, Januari 2001: 58-65. 